\title{
PROFIL KOMUNIKASI MATEMATIS SISWA SMP DALAM MENYELESAIKAN SOAL MATEMATIKA DITINJAU DARI SELF EFFICACY
}

\author{
Risa Liawati \\ Pendidikan Matematika, Fakultas Matematika dan Ilmu Pengetahuan Alam, Universitas Negeri Surabaya \\ e-mail: risaliawati16030174009@mhs.unesa.ac.id \\ Pradnyo Wijayanti \\ Pendidikan Matematika, Fakultas Matematika dan Ilmu Pengetahuan Alam, Universitas Negeri Surabaya \\ e-mail: pradnyowijayanti@unesa.ac.id
}

\begin{abstract}
Abstrak
Komunikasi adalah cara penyampaian pesan antar manusia dengan tujuan agar pesan yang akan disampaikan dapat dipahami. Dalam pembelajaran matematika, siswa diharuskan untuk mempunyai kemampuan komunikasi yang baik dan jelas. Penelitian ini merupakan penelitian deskriptif dengan menggunakan pendekatan kualitatif yang bertujuan untuk mendeskripsikan profil komunikasi matematis siswa SMP dalam menyelesaikan soal matematika ditinjau dari self efficacy. Instrumen yang digunakan yaitu angket self efficacy, tes kemampuan matematika, tes komunikasi matematis, dan wawancara. Subjek dalam penelitian ini adalah satu siswa kelas IX dengan self efficacy tinggi dan satu siswa kelas IX dengan self efficacy rendah. Hasil penelitian menunjukkan bahwa siswa dengan self efficacy tinggi memiliki komunikasi matematis sebagai berikut.1) Akurat, lengkap, lancar dalam menuliskan hal-hal yang diketahui dan ditanyakan pada soal. 2) Akurat, lengkap, lancar dalam menuliskan pernyataan pada soal ke dalam model matematika. 3) Akurat, lengkap, lancar dalam menuliskan ide atau relasi matematis untuk menyelesaikan soal yang diberikan. 4) Akurat, tidak lengkap, lancar dalam menuliskan langkah-langkah penyelesaian soal menuju solusi akhir secara matematis. 5) Akurat, lengkap, lancar dalam menuliskan alasan terkait dengan solusi matematika dalam konteks semula. Sedangkan siswa dengan self efficacy rendah memiliki komunikasi matematis sebagai berikut. 1) Akurat, tidak lengkap, lancar dalam menuliskan hal-hal yang diketahui dan ditanyakan pada soal. 2) Akurat, lengkap, lancar dalam menuliskan pernyataan pada soal ke dalam model matematika. 3) Akurat, lengkap, lancar dalam menuliskan ide atau relasi matematis untuk menyelesaikan soal yang diberikan. 4) Akurat, tidak lengkap, tidak lancar dalam menuliskan langkah-langkah penyelesaian soal menuju solusi akhir secara matematis. 5) Akurat, lengkap, lancar dalam menuliskan alasan terkait dengan solusi matematika dalam konteks semula. Penelitian ini memberikan gambaran bahwa self efficacy yang dimiliki siswa memberi pengaruh terhadap komunikasi matematisnya dalam menyelesaikan soal matematika.
\end{abstract} Kata Kunci: Komunikasi matematis, Self efficacy

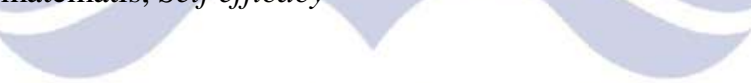

Communication is the way of delivering messages with the aim of order that the message to be submitted can be understood. In learning mathematics, students are required to have good and clear communication skills. This research is descriptive research using a qualitative approach that aims to describe the mathematical communication profile of junior high school students in solving mathematical task in terms of self efficacy. The instrument used is questionnaire self efficacy, mathematical ability test, mathematical communication test, and interview. Subjects in this research are one student with high self efficacy and one student with low self efficacy. The results showed that student with high self efficacy have the following mathematical communication as follows. 1) Accurate, complete, and fluent in write down the things that are known and asked. 2) Accurate, complete, and fluent in write down the statement in the task into math models. 3) Accurate, complete, and fluent in write down ideas, situations or mathematical relations in mathematical task given. 4) Accurate, incomplete, and fluent in write down mathematical task solving steps towards the final solution mathematically. 5) Accurate, complete, and fluent in write down the reasons related to mathematical solutions in the original context. While student with low self efficacy have the following mathematical communication as follows. 1) Accurate, incomplete, and fluent in write down the things that are known and asked. 2) Accurate, complete, and fluent in write down the statement in the task into math models. 3) Accurate, complete, and fluent in write down ideas, situations or mathematical relations in mathematical task given. 4) Accurate, incomplete, and influent in write down mathematical task solving steps towards the final solution mathematically. 5) Accurate, complete, and fluent in write down the reasons related 
to mathematical solutions in the original context. This research provides an overview that self efficacy owned students influence the mathematical communication in solving mathematical task.

Keywords: Mathematical Communication, Self efficacy

\section{PENDAHULUAN}

Matematika merupakan salah satu mata pelajaran yang mempelajari tentang bilangan, yang mana di dalamnya mengandung simbol-simbol yang masih bersifat abstrak. Simbol-simbol matematika tersebut berperan sebagai bahasa simbolik yang memungkinkan terjadinya sebuah komunikasi secara tepat dan cermat. Sehingga matematika tak hanya sebagai alat bantu berfikir saja, namun matematika juga sebagai wahana komunikasi antara siswa dengan siswa maupun siswa dengan guru.

$\operatorname{NCTM}$ (2000) mengatakan bahwa terdapat enam kemampuan penting yang perlu dikembangkan dalam pembelajaran matematika, yaitu (1) pemahaman konsep, (2) pemecahan masalah, (3) penalaran dan pembuktian, (4) komunikasi, (5) koneksi, (6) representasi. Dalam kurikulum 2013, komunikasi memiliki peran penting dalam proses pembelajaran. Hal ini disebabkan adanya tuntutan bahwa proses pembelajaran tidak hanya berpusat pada guru saja, melainkan siswa dituntut aktif dalam membangun sendiri pengetahuannya. Salah satu cara untuk membangun pengetahuan siswa bisa melalui berbagai aktivitas yang melibatkan komunikasi.

Kemampuan komunikasi yang baik dan jelas harus dimiliki oleh siswa. Kegiatan berkomunikasi tidak hanya dilakukan dengan tanya jawab maupun diskusi antara siswa dengan siswa maupun siswa dengan guru, namun komunikasi juga dapat dilakukan dengan memecahkan soal matematika. Terkadang jika siswa memperoleh soal dari guru untuk dikerjakan, siswa tidak selalu dituntut untuk menyelesaikan soal sesuai dan sama persis dengan cara yang diberikan oleh güru, melainkan siswa juga diberi kebebasan untuk diperbolehkan mengerjakan dengan caranya sendiri. Agar guru dapat memahami apa yang dimaksud siswa dalam penyelesaian soal tersebut, diperlukan sebuah komunikasi matematis yang baik dan jelas.

Komunikasi merupakan cara penyampaian pesan antar manusia dengan tujuan agar pesan yang akan disampaikan dapat dipahami. Melalui komunikasi, seseorang dapat menerima informasi, saling bersosialisasi, serta mengekspresikan ide dan pemikirannya.

Dewi (2009), mengategorikan komunikasi matematis menjadi dua, yaitu komunikasi matematis tulis dan komunikasi matematis lisan. Komunikasi matematis tulis biasanya terdapat pada hasil pengerjaan soal oleh siswa, baik berupa pemodelan, persamaan, diagram, tabel, maupun grafik. Sedangkan komunikasi matematis lisan biasanya terdapat pada saat siswa melakukan presentasi mengenai hasil kerjanya.

Salah satu faktor penting dalam berkomunikasi adalah adanya kepercayaan akan kemampuan diri. Hal ini penting untuk menunjang terlaksananya komunikasi baik lisan maupun tulisan yang lancar dan dapat dipahami. Komunikasi yang baik diperlukan dalam menyelesaikan tugas matematika sehingga ide dapat disampaikan seperti yang dimaksudkan. Self efficacy adalah kepercayaan atau keyakinan diri terhadap kemampuan yang dimiliki seseorang dalam menyelesaikan tugas matematika termasuk persepsi terhadap tugas, keyakinan terhadap kemampuan diri, kemampuan memprediksi hasil, dan kemampuan diri dalam menghadapi situasi (Sadewi, 2012).

Bandura (dalam Ayotola \& Adedeji, 2009) mengatakan, kemampuan seseorang dalam menyelesaikan tugas akademik dapat diprediksi berdasarkan self efficacy. Bandura juga menyampaikan bahwa self efficacy yang dimiliki seseorang berperan dalam menentukan prestasi matematika dan kemampuannya dalam menulis. Dalam penelitian lain, dijelaskan bahwa tingkat self efficacy yang dimiliki oleh seseorang memiliki pengaruh penting dalam menyelesaikan masalah matematika. Zimermann (2015) menyatakan bahwa self efficacy dalam matematika lebih berperan ketika menyelesaikan masalah dari pada ketika mempelajari konsep matematika itu sendiri. Sehingga self efficacy lebih berpengaruh pada penerapan matematika dan pengalaman sebelumnya.

Desmawati (2015) mengatakan bahwa terdapat hubungan positif antara self efficacy dan kemampuan komunikasi matematis siswa, yang berarti bahwa semakin tinggi self efficacy siswa, maka kemampuan komunikasi matematis siswa akan tinggi. Begitupun sebaliknya jika self efficacy rendah, maka kemampuan komunikasi matematis siswa juga rendah. Ketika mereka merasa punya kelebihan akan sesuatu, maka mereka akan yakin akan dirinya bahwa mereka mampu melakukan sesuatu tersebut. Siswa dengan self efficacy rendah akan merasa kurang mampu menyelesaikan persoalan tentang 
matematika, mereka akan mengganggap itu adalah sebuah kegagalan dan kemudian menyerah. Namun ketika ada di antara mereka yang mempunyai keyakinan akan dirinya untuk bisa terus belajar dan mengganggap ketidakbisaan sebagai kurangnya usaha, maka mereka inilah yang memiliki self efficay tinggi. Siswa dengan self efficacy tinggi akan berusaha belajar matematika yang mereka anggap susah, sehingga mereka bisa memecahkan persoalannya. Ketika mereka bisa memecahkan persoalan matematika dengan banyak pola, simbol, gambar, angka dan sebagainya, maka kemampuan komunikasi akan matematikanya sangat baik.

Telah dilakukan penelitian mengenai hubungan antara self efficacy dan kemampuan komunikasi matematis siswa (Desmawati, 2015), namun dalam penelitian tersebut belum dibahas lebih mengenai profil komunikasi matematis siswa ditinjau dari self efficacy. Pengetahuan mengenai profil komunikasi ini penting untuk diketahui guru sehingga guru mempunyai gambaran jelas mengenai komunikasi matematis siswa dengan self efficacy tinggi maupun rendah. Gambaran inilah yang nantinya dapat dijadikan pedoman atau pengetahuan dasar dalam membantu melatih komunikasi matematis siswa terutama siswa dengan self efficacy rendah. Untuk itu perlu diadakan penelitian mengenai profil komunikasi matematis siswa berdasarkan self efficacy. OECD (2013) menyebutkan aktivitas komunikasi matematis yang terlibat dalam menyelesaikan soal matematika adalah sebagai berikut. (1) Membaca, menerjemahkan kode/sandi, memahami pernyataan, pertanyaan, tugas, objek atau gambar untuk membentuk model mental situasi, (2) Mengartikulasikan solusi, menunjukkan kerja yang digunakan dalam mencapai solusi serta meringkas dan atau mempresentasikan hasil matematis, (3) Mengonstruksi dan mengomunikasikan penjelasan dan argument yang ada dalam konteks masalah. Sementara Rausch (2017) mengatakan bahwa pada komunikasi terdapat tiga aspek yaitu keakuratan, kelengkapan, dan kelancaran. Indikator yang digunakan dalam melihat komunikasi matematis siswa merujuk pada aktivitas komunikasi matematis siswa yang terlibat dalam menyelesaikan soal matematika dan dikaitkan dengan tiga aspek komunikasi. Penelitian ini memiliki tujuan untuk mendeskripsikan profil komunikasi matematis siswa SMP dalam menyelesaikan soal matematika ditinjau dari self efficacy. Namun dalam penelitian ini, akan difokuskan pada komunikasi matematis tulis, dikarenakan dengan menulis siswa dapat membentuk kecakapan komunikasi matematisnya. Melalui komunikasi matematis tulis, siswa dapat mengorganisasi, merangkum, dan mengomunikasikan pemikiran mereka, serta dapat mencakup pengungkapan apa yang sudah diketahui atau dipahami dan apa yang belum dipahami (Mahmudi, 2009).

\section{METODE}

Jenis penelitian ini ialah penelitian deskriptif dengan menggunakan pendekatan kualitatif. Penelitian ini memiliki tujuan untuk mendeskripsikan profil komunikasi matematis siswa SMP dalam menyelesaikan soal matematika ditinjau dari self efficacy. Dalam penelitian ini terdapat empat instrumen yang digunakan, yaitu angket self efficacy, tes kemampuan matematika, tes komunikasi matematis, serta pedoman wawancara. Angket self efficacy dan tes kemampuan matematika digunakan untuk menentukan subjek dengan self efficacy tinggi dan subjek dengan self efficacy rendah serta memiliki kemampuan matematika setara. Angket self efficacy yang digunakan dalam penelitian ini merujuk pada penelitian yang telah dilakukan oleh Anggraini (2017). Tes komunikasi matematis dikerjakan oleh subjek terpilih dan selanjutnya dilakukan wawancara terhadap subjek tersebut. Tujuan wawancara untuk menggali informasi yang belum terungkap melalui tes tulis. Analisis data yang digunakan yaitu analisis data hasil angket self efficacy, hasil tes kemampuan matematika, hasil tes komunikasi matematis, dan hasil wawancara. Angket self efficacy dianalisis menggunakan pedoman skor self efficacy serta penggolongan self efficacy dapat dilihat pada tabel berikut.

Tabel 1. Kategori Self Efficacy

\begin{tabular}{|c|c|c|}
\hline No & Rentang Skor & Kategori Self Efficacy \\
\hline 1 & $42<$ skor angket $\leq 70$ & Tinggi \\
\hline 2 & $14 \leq$ skor angket $<42$ & Rendah \\
\hline
\end{tabular}

Skor 42 tidak termasuk dalam kategori apapun, dikarenakan 42 adalah skor netral. Sehingga skor self efficacy rendah ialah di bawah 42 dan skor self efficacy tinggi ialah di atas 42. Tes kemampuan matematika dianalisis secara kuantitatif dan hasil tes ditulis dalam skala 0-100. Tes komunikasi matematis dianalisis menggunakan indikator komunikasi matematis tulis. Sedangkan data hasil wawancara dianalisis melalui tahapan reduksi data, penyajian data, dan penarikan kesimpulan (Miles \& Huberman, 2014)

\section{HASIL DAN PEMBAHASAN}

Setelah dilakukan pemilihan subjek, peneliti memberikan tes komunikasi matematis kepada subjek yang telah terpilih. Berikut akan dipaparkan mengenai hasil tes komunikasi matematis subjek dengan self efficacy tinggi dan self efficacy rendah. 
Profil Komunikasi Matematis Subjek dengan Self Efficacy Tinggi (ST) dalam Menyelesaikan Soal Matematika

a. Menuliskan hal-hal yang diketahui dan ditanyakan pada soal

\begin{tabular}{rl|}
\hline Diket 3 hoodie +2 kemeja $=455000$ \\
hoodic lebih mahal daripada keinga \\
Ditanya harga masing-masing hoodic dan keimeja?
\end{tabular}

Gambar 1. Hasil Jawaban ST

Pada Gambar 1, terlihat bahwa ST menuliskan hal-hal yang diketahui dan ditanyakan dengan benar dan sesuai dengan informasi yang ada pada soal. ST menuliskannya secara urut sesuai urutan informasi yang tertera pada soal dan menuliskan semuanya dengan lengkap tanpa ada informasi yang terlewat serta menuliskan semuanya dengan tidak terdapat coretan atau koreksian pada lembar jawabannya. Berdasarkan hal tersebut, dapat dikatakan bahwa ST akurat, lengkap dan lancar dalam menuliskan hal-hal yang diketahui dan ditanyakan pada soal.

b. Menuliskan pernyataan, pertanyaan, tugas, objek atau gambar ke dalam model matematika atau menggunakan representasi secara verbal, grafik, diagram atau simbolik

$\begin{aligned} \text { Jamab: Hoodie } & =x \\ \text { Kemeja } & =y \\ 3 x+2 y & =455.000\end{aligned}$

Gambar 2. Hasil Jawaban ST

Pada Gambar 2, terlihat bahwa ST menuliskan pernyataan dalam soal ke dalam model matematika dengan benar. ST membuat permisalan untuk masingmasing jenis pakaian, yaitu hoodie dimisalkan dengan huruf $x$ dan kemeja dimisalkan dengan huruf $y$. ST juga membuat permisalan dari informasi yang diketahui pada soal, yaitu 3 hoodie dan 2 kemeja dengan harga $R p 455.000$ yang kemudian oleh ST dimodelkan menjadi $3 x+2 y=455.000$. Namun dalam lembar jawabannya, ST tidak menuliskan kalimat permisalan. ST menuliskan pernyataan yang terdapat dalam soal ke dalam bentuk model matematika dengan tidak adanya coretan atau koreksian pada lembar jawabannya. Berdasarkan hal tersebut, dapat dikatakan bahwa ST akurat, lengkap dan lancar dalam menuliskan pernyataan, pertanyaan, tugas, objek atau gambar ke dalam model matematika atau menggunakan representasi secara verbal, grafik, diagram atau simbolik.

c. Menuliskan ide, situasi atau relasi matematis untuk menyelesaikan soal

\begin{tabular}{l} 
karena Revina menukar kemeja dengan hoodie, dan ia harus membayor \\
35000 . maka \\
$\begin{array}{ll}9 x+y=490000 \quad(455000+35000) & \text { (Persamaan 1) } \\
3 x+2 y=455000 & \text { (Persamaan 2) }\end{array}$ \\
\hline
\end{tabular}

Gambar 3. Hasil Jawaban ST

Peneliti : Apakah kamu sudah memahami maksud dari soal yang diberikan?

ST : Sudah kak

Peneliti : Setelah memahami soal, apakah kamu sudah memikirkan ide untuk penyelesaian soal tersebut?

ST : Sudah kak

Peneliti : Ide seperti apa yang kamu gunakan untuk menyelesaikan soal?

ST : Saya melihat persamaan awal yang sudah diketahui, yaitu harga 3 hoodie dan 2 kemeja adalah Rp 455.000. Kemudian ada informasi tambahan, yaitu 1 kemeja ditukar dengan 1 hoodie dan harus membayar lagi sebesar Rp 35.000. Berarti sekarang kan jumlah hoodienya ada 4 dan kemejanya ada 1 serta total biaya yang dikeluarkan adalah $\quad R p \quad 490.000$, dan persamaannya menjadi $4 \mathrm{x}+\mathrm{y}=$ 490.000. Sebenarnya saya punya satu ide lagi untuk membentuk persamaan barunya kak, yaitu dengan membuat persamaan baru yaitu $x=y+35.000$. Namun karena di soal tidak ada perintah mengerjakan dengan cara lain, jadi saya tulis satu saja.

Peneliti : Setelah itu, apa yang kamu lakukan?

ST : Saya menuliskan bahwa ada 2 persamaan. Persamaan 1 yaitu persamaan baru yang saya dapatkan, dan persamaan 2 adalah persamaan yang sudah diketahui dari soal. 
Berdasarkan hasil pekerjaan pada Gambar 3 dan wawancara, terlihat bahwa ST menuliskan ide, situasi atau relasi matematis untuk menyelesaikan soal yang diberikan dengan benar. ST memiliki ide yang matematis dan logis. Representasi yang digunakan adalah dengan cara membentuk persamaan baru. Pernyataan awal yaitu Revina membeli 3 hoodie dan 2 kemeja dengan harga Rp 455.000 yang kemudian oleh ST dimodelkan menjadi $3 \mathrm{x}+2 \mathrm{y}=455.000$. Namun, ada penukaran barang. Revina menukarkan 1 kemejanya dengan 1 hoodie dan Revina harus membayar lagi sebesar Rp 35.000 . Pernyataan tersebut oleh ST dibentuk menjadi persamaan baru, $4 \mathrm{x}+\mathrm{y}=490.000$ dikarenakan jumlah hoodie yang dimiliki Revina sekarang adalah 4, kemeja sebanyak 1, dan total uang yang digunakan untuk membeli pakaian tersebut sebesar Rp 490.000. Dalam menuliskan idenya ST menggunakan semua elemen yang diberikan pada soal. ST menggunakan persamaan awal dan persamaan baru yang telah dibuat untuk menentukan nilai dari masing-masing variabel. ST menuliskan idenya dari awal hingga akhir secara runtut serta tidak terdapat adanya coretan atau koreksian pada lembar jawabannya. Sehingga dapat dikatakan bahwa ST akurat, lengkap, dan lancar dalam menuliskan ide, situasi atau relasi matematis untuk menyelesaikan soal.

d. Menuliskan langkah-langkah penyelesaian soal menuju solusi akhir secara matematis

\begin{tabular}{|c|}
\hline $\begin{aligned} \text { Diket } 3 \text { hoodic }+2 \text { kemeja }=455000 \\
\text { hoodie lebih mahal daripada kemeja }\end{aligned}$ \\
\hline $\begin{array}{l}\text { hoodie lebih mahal daripada kemeja } \\
\text { Ditanya harga masing-masing hoodie dan keineja? }\end{array}$ \\
\hline 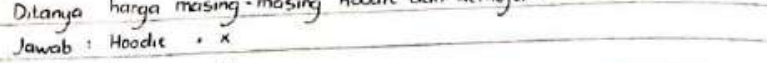 \\
\hline Jawab kemeja $=y$ \\
\hline $3 x+2 y=455.000$ \\
\hline Karena Revina inenukar kemeja dengan hoodie, dan la harus membayar \\
\hline 35000 . maka \\
\hline $4 x+y=490000 \quad(455000+35.000) \quad$ (Persamaan 1) \\
\hline $3 x+2 y=455000 \quad$ (Persamaan 2) \\
\hline $8 x+2 y \cdot 980000$ \\
\hline $3 x+2 y=455000$ \\
\hline $5 x=525000$ \\
\hline$\times \quad=525000$ \\
\hline 5 \\
\hline$=105000$ \\
\hline Substitusi $\times$ ke persamaan 1 \\
\hline $4 x+y=490000$ \\
\hline $4(105000)+y=490000$ \\
\hline $420.000+y=490.000$ \\
\hline$y=70.000$ \\
\hline Jadi, harga hoodie adalah $R_{p} 105.000$ \\
\hline harga kemeja adalah $R_{p} 70.000$ \\
\hline ec. Scanned with \\
\hline
\end{tabular}

Gambar 4. Hasil Jawaban ST

Peneliti : Apakah kamu sudah yakin dengan jawaban yang kamu peroleh?

ST : Yakin kak.

Peneliti : Apa yang kamu lakukan setelah memperoleh jawaban, apakah mengecek kembali jawabanmu benar atau tidak?

ST : Tidak kak.

Peneliti : Apakah jawaban yang kamu peroleh sudah menjawab soal?

ST : Sudah kak. Jawaban yang saya peroleh sesuai dengan informasi yang ada pada soal, yaitu harga 1 hoodie lebih mahal daripada harga

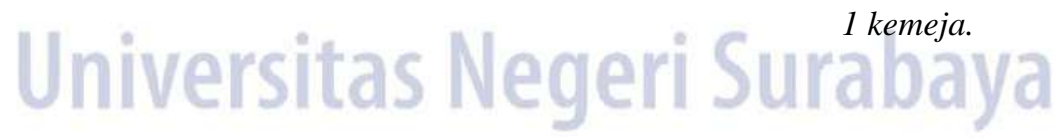

Berdasarkan hasil pekerjaan pada Gambar 4 dan wawancara, terlihat bahwa ST menuliskan langkahlangkah yang digunakan untuk menyelesaikan soal dan melakukan perhitungan dengan benar hingga menuju solusi akhir. Pada Gambar 4 juga tampak bahwa ST menggunakan metode campuran untuk menentukan nilai dari masing-masing variabel, namun dalam lembar jawabannya, ST tidak menuliskan metode yang digunakan. ST langsung mengeliminasi dan mensubtitusi persamaan (1) dan (2). ST mengerjakan dan menuliskan langkah demi 
langkah secara runtut dari awal hingga akhir dan dengan tidak adanya coretan atau koreksian pada lembar jawabannya. Sehingga dapat dikatakan bahwa ST akurat, tidak lengkap, dan lancar dalam menuliskan langkah-langkah penyelesaian soal menuju solusi akhir secara matematis.

e. Menuliskan alasan terkait dengan solusi matematika dalam konteks semula

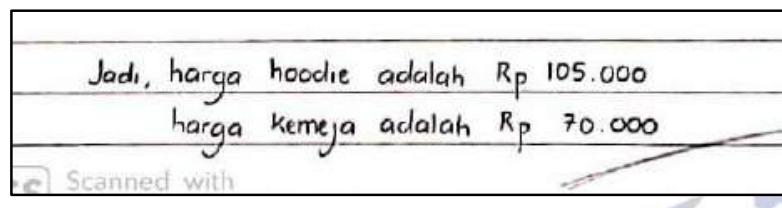

Gambar 5. Hasil Jawaban ST

Pada Gambar 5, terlihat bahwa ST menuliskan alasan terkait dengan solusi matematika dalam konteks semula dengan akurat. ST memperoleh solusi akhir sesuai dengan yang ditanyakan pada soal. Dalam soal ditanyakan harga dari masing-masing hoodie dan kemeja, solusi yang diperoleh ST yaitu harga hoodie Rp 105.000 dan harga kemejaRp 70.000. Jawaban ST sesuai dengan konteks semula dikarenakan solusi yang diperoleh berupa bilangan yang memungkinkan, yaitu bilangan asli yang menyatakan harga dari masing-masing hoodie dan kemeja.

ST menuliskan alasan terkait dengan solusi matematika dalam konteks semula dan memperoleh solusi dari soal yang diberikan dengan lengkap beserta satuannya serta dengan tidak adanya coretan atau koreksian pada lembar jawabannya. Sehingga dapat dikatakan bahwa ST akurat, lengkap, dan lancar dalam menuliskan alasan terkait dengan solusi matematika dalam konteks semula.

Profil Komunikasi Matematis Subjek dengan Self Efficacy Rendah (SR) dalam Menyelesaikan Soal Matematika

a. Menuliskan hal-hal yang diketahui dan ditanyakan pada soal

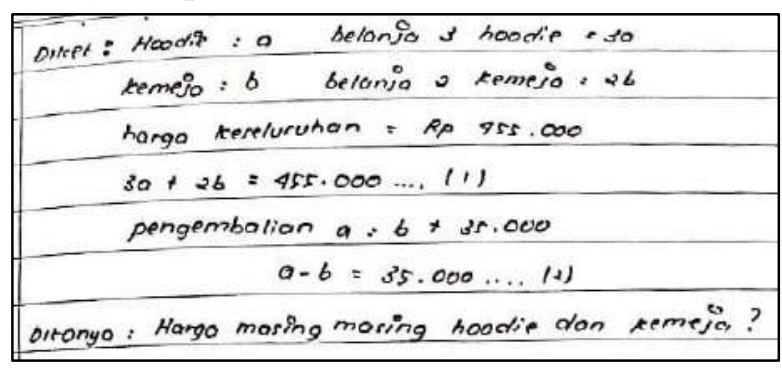

Gambar 6. Hasil Jawaban SR
Pada Gambar 6, terlihat bahwa SR menuliskan hal-hal yang diketahui dan ditanyakan dengan benar dan sesuai dengan informasi yang ada pada soal. SR menuliskannya secara urut sesuai urutan informasi yang tertera pada soal. Namun SR menuliskan informasi yang ada pada soal dengan tidak lengkap. Ada hal yang diketahui pada soal, dan tidak ditulis dalam lembar jawabannya. Hal tersebut adalah harga hoodie lebih mahal daripada harga kemeja serta menuliskan semuanya dengan tidak terdapat coretan atau koreksian pada lembar jawabannya. Berdasarkan hal tersebut, dapat dikatakan bahwa ST akurat, tidak lengkap dan lancar dalam menuliskan hal-hal yang diketahui dan ditanyakan pada soal.

b. Menuliskan pernyataan, pertanyaan, tugas, objek atau gambar ke dalam model matematika atau menggunakan representasi secara verbal, grafik, diagram atau simbolik

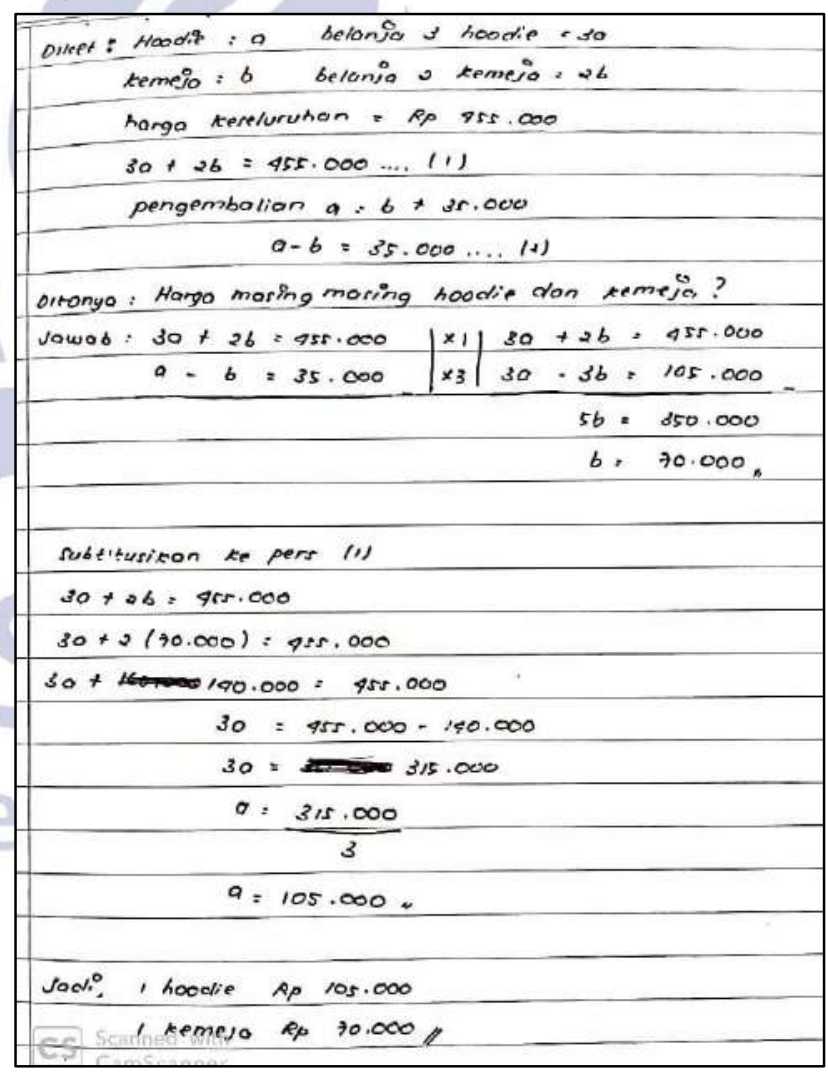

Gambar 7. Hasil Jawaban SR

Pada Gambar 7, terlihat bahwa SR menuliskan pernyataan dalam soal ke dalam model matematika dengan benar. SR membuat permisalan untuk masingmasing jenis pakaian, yaitu hoodie dimisalkan dengan huruf $a$ dan kemeja dimisalkan dengan huruf $b$. SR juga membuat permisalan dari informasi yang diketahui pada soal, yaitu 3 hoodie dan 2 kemeja 
dengan harga $R p 455.000$ yang kemudian oleh SR dimodelkan menjadi $3 a+2 b=455.000$. Namun dalam lembar jawabannya, SR tidak menuliskan kalimat permisalan. SR menuliskan pernyataan yang terdapat dalam soal ke dalam bentuk model matematika dengan tidak adanya coretan atau koreksian pada lembar jawabannya. Berdasarkan hal tersebut, dapat dikatakan bahwa SR akurat, lengkap dan lancar dalam menuliskan pernyataan, pertanyaan, tugas, objek atau gambar ke dalam model matematika atau menggunakan representasi secara verbal, grafik, diagram atau simbolik.

c. Menuliskan ide, situasi atau relasi matematis untuk menyelesaikan soal

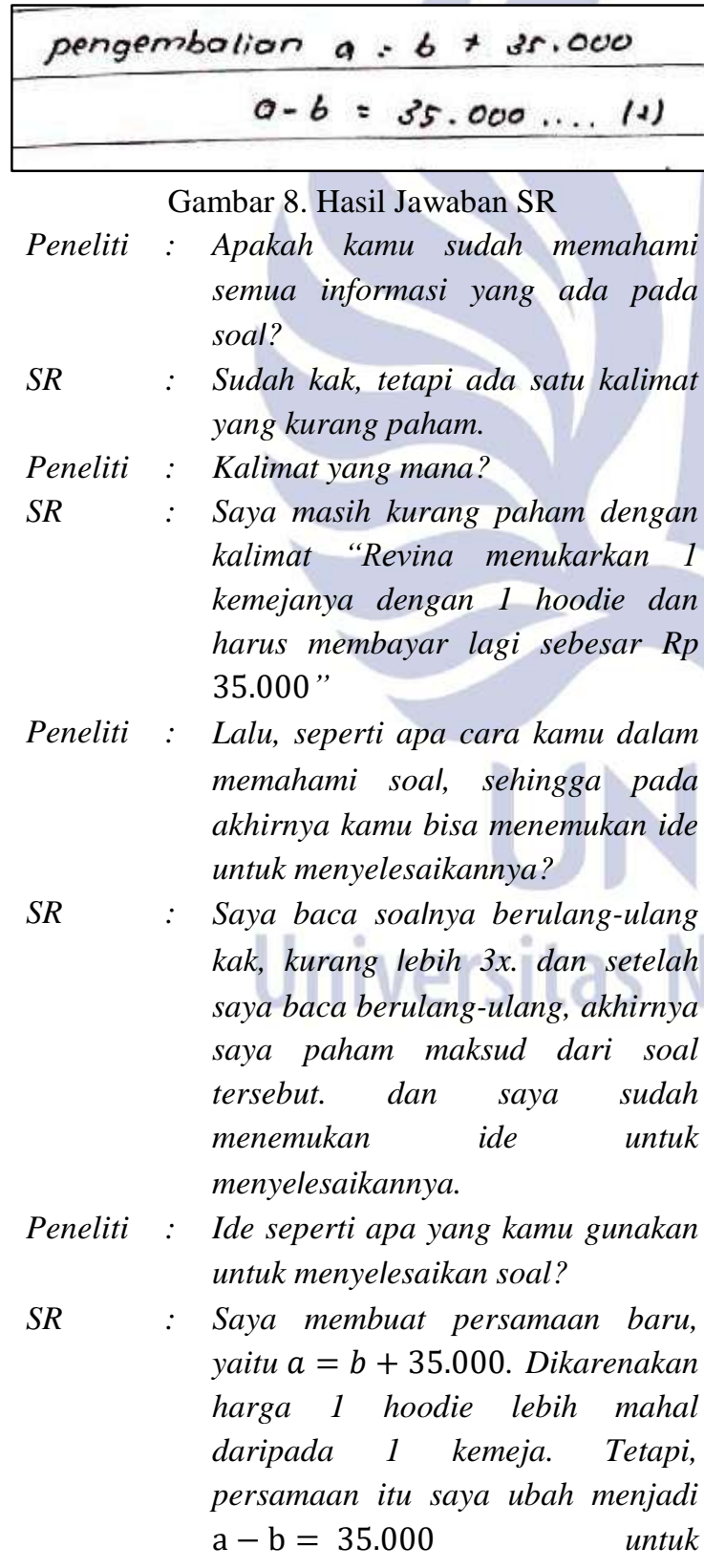

mempermudah saya dalam
mengerjakan soal.

Berdasarkan hasil pekerjaan pada Gambar 8 dan wawancara, terlihat bahwa SR menuliskan ide, situasi atau relasi matematis untuk menyelesaikan soal yang diberikan dengan benar. SR memiliki ide yang matematis dan logis. Representasi yang digunakan adalah dengan cara membentuk persamaan baru. Pernyataan awal yaitu Revina membeli 3 hoodie dan 2 kemeja dengan harga Rp 455.000 yang kemudian oleh SR dimodelkan menjadi $3 a+2 b=455.000$. Namun, ada penukaran barang. Revina menukarkan 1 kemejanya dengan 1 hoodie dan Revina harus membayar lagi sebesar Rp 35.000 . Pernyataan tersebut oleh SR dibentuk menjadi persamaan baru,yaitu $\mathrm{a}=\mathrm{b}+35.000$. Namun untuk mempermudah perhitungan, SR memindahkan variabel $b$ ke ruas kiri sehingga persamaannya menjadi $\mathrm{a}-\mathrm{b}=35.000$.

Dalam menuliskan idenya, SR menggunakan semua elemen yang diberikan pada soal. SR menggunakan persamaan awal dan persamaan baru yang telah dibuat untuk menentukan nilai dari masing-masing variabel. SR menuliskan idenya dari awal hingga akhir secara runtut serta tidak terdapat adanya coretan atau koreksian pada lembar jawabannya. Sehingga dapat dikatakan bahwa SR akurat, lengkap, dan lancar dalam menuliskan ide, situasi atau relasi matematis untuk menyelesaikan soal.

d. Menuliskan langkah-langkah penyelesaian soal menuju solusi akhir secara matematis

Peneliti : Apa kamu sudah yakin dengan hasil jawaban yang kamu peroleh?

SR : Awalnya saya tidak yakin kak, raguragu dan takut salah. Tetapi setelah saya cek dan hasilnya sesuai, saya yakin.

Peneliti : Bagaimana cara kamu mengecek jawabanmu?

SR : Saya coba untuk mensubstitusikan harga hoodie dan kemeja ke persamaan 1 dan 2. Ternyata hasilnya sesuai kak.

Berdasarkan hasil pekerjaan pada Gambar 7 dan wawancara, terlihat bahwa SR menuliskan langkahlangkah yang digunakan untuk menyelesaikan soal dan melakukan perhitungan dengan benar hingga 
menuju solusi akhir. Pada Gambar 7 juga tampak bahwa SR menggunakan metode campuran untuk menentukan nilai dari masing-masing variabel, namun dalam lembar jawabannya, SR tidak menuliskan metode yang digunakan. SR langsung mengeliminasi dan mensubtitusi persamaan (1) dan (2). SR mengerjakan dan menuliskan langkah demi langkah secara runtut dari awal hingga akhir. Namun dalam lembar jawabannya, terdapat adanya coretan atau koreksian. Terlihat bahwa SR melakukan beberapa kali kesalahan dalam melakukan perhitungan pada saat mensubstitusikan nilai variabel $b$ ke persamaan 1. Berdasarkan hal tersebut, dapat dikatakan bahwa SR akurat, tidak lengkap, dan tidak lancar dalam menuliskan langkah-langkah penyelesaian soal menuju solusi akhir secara matematis.

e. Menuliskan alasan terkait dengan solusi matematika dalam konteks semula

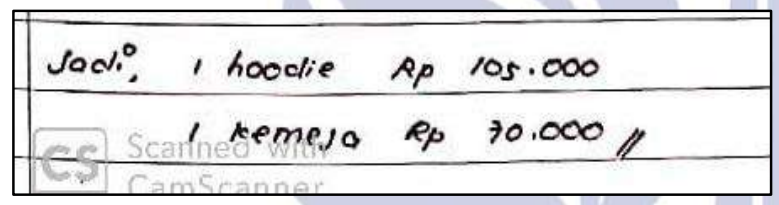

Gambar 9. Hasil Jawaban SR

Pada Gambar 9, terlihat bahwa SR menuliskan alasan terkait dengan solusi matematika dalam konteks semula dengan akurat. SR memperoleh solusi akhir sesuai dengan yang ditanyakan pada soal. Dalam soal ditanyakan harga dari masing-masing hoodie dan kemeja, solusi yang diperoleh SR yaitu harga hoodie Rp 105.000 dan harga kemeja Rp 70.000. Jawaban SR sesuai dengan konteks semula dikarenakan solusi yang diperoleh berupa bilangan yang memungkinkan, yaitu bilangan asli yang menyatakan harga dari masing-masing hoodie dan kemeja.

SR menuliskan alasan terkait dengan solusi matematika dalam konteks semula dan memperoleh solusi dari soal yang diberikan dengan lengkap beserta satuannya serta dengan tidak adanya coretan atau koreksian pada lembar jawabannya. Sehingga dapat dikatakan bahwa SR akurat, lengkap, dan lancar dalam menuliskan alasan terkait dengan solusi matematika dalam konteks semula.

\section{PEMBAHASAN}

Dari hasil tes tertulis dan wawancara, terlihat bahwa siswa dengan self efficacy tinggi akurat, lengkap dan lancar dalam menuliskan hal-hal yang diketahui dan ditanyakan pada soal. Siswa dengan self efficacy tinggi menuliskan hal-hal yang diketahui dan ditanyakan pada soal secara urut sesuai urutan informasi yang tertera pada soal. Siswa dengan self efficacy tinggi akurat, lengkap dan lancar dalam menuliskan pernyataan dalam soal ke dalam model matematika. Siswa dengan self efficacy tinggi memodelkan pernyataan yang diketahui pada soal menjadi persamaan baru, yaitu $3 \mathrm{x}+2 \mathrm{y}=455.000$ dan memisalkan hoodie dan kemeja dengan variabel $x$ dan $y$. Siswa dengan self efficacy tinggi mempunyai ide lebih dari satu untuk menyelesaikan soal tersebut. Namun dalam soal hanya dituliskan satu ide saja. Hal tersebut sesuai dengan karakteristik siswa dengan self efficacy tinggi yaitu mampu mengembangkan gagasan, cara atau ide yang dimiliki melalui pengalaman baru (Djalali, 2012). Siswa dengan self efficacy tinggi akurat, tidak lengkap, dan lancar dalam menuliskan langkah-langkah penyelesaian soal. Langkah pertama yaitu membuat permisalan untuk masing-masing jenis pakaian, langkah kedua yaitu membuat satu persamaan baru sesuai dengan informasi yang ada di soal, yaitu terdapat pengembalian barang. Langkah ketiga yaitu menggunakan metode campuran untuk mendapatkan nilai dari masing-masing variabel dan langkah terakhir yaitu menuliskan solusi matematika ke dalam konteks semula. Setelah mendapatkan solusi, siswa dengan self efficacy tinggi tidak memeriksa kembali jawabannya dikarenakan sudah sangat yakin dengan apa yang telah dikerjakan. Hal tersebut sesuai dengan pendapat Zimermann (2015) bahwa self efficacy sangat berperan dalam menyelesaikan soal matematika, dan juga sesuai dengan pendapat Bandura (dalam Ayotola \& Adedeji, 2009) yang mengatakan bahwa siswa dengan self efficacy tinggi merasa yakin akan kemampuan dalam dirinya dalam melakukan suatu tugas akademik. Sedangkan siswa dengan self efficacy rendah hanya memiliki satu ide untuk menyelesaikan soal dan tampak kebingungan dalam menemukan ide tersebut. Siswa dengan self efficacy rendah membaca soal berkalikali untuk bisa memahami maksud dari soal tersebut. Hal tersebut sesuai dengan karakteristik siswa dengan self efficacy rendah yaitu tidak mampu mengembangkan gagasan, cara atau ide yang dimiliki melalui pengalaman baru (Djalali, dkk., 2012) dan juga sesuai dengan pendapat Rahmawati (2015) bahwa siswa dengan self efficacy rendah cenderung mengalami kesulitan saat memahami peristiwa dan menujukkan depresi, serta memiliki wawasan yang rendah tentang cara terbaik untuk menyelesaikan tugas. Setelah mendapatkan solusi akhir, siswa dengan self efficacy rendah memeriksa kembali jawabannya dikarenakan siswa dengan self efficacy rendah masih kurang yakin dengan hasil yang diperoleh dan apa yang 
telah dikerjakan. Hal tersebut sesuai dengan pendapat Bandura (dalam Ayotola \& Adedeji, 2009) yang mengatakan bahwa siswa dengan self efficacy rendah merasa tidak yakin akan kemampuan dalam dirinya dalam melakukan suatu tugas akademik.

\section{PENUTUP}

\section{Simpulan}

Berdasarkan hasil analisis data yang telah diperoleh, maka simpulan profil komunikasi matematis siswa SMP dalam menyelesaikan soal matematika ditinjau dari self efficacy ialah sebagai berikut.

1. Profil Komunikasi Matematis Siswa dengan Self Efficacy Tinggi dalam Menyelesaikan Soal Matematika

Siswa dengan self efficacy tinggi mampu menuliskan hal-hal yang diketahui dan ditanyakan pada soal dengan akurat, lengkap dan lancar. Siswa dengan self efficacy tinggi menuliskan pernyataan dalam soal ke dalam model matematika dengan akurat, lengkap dan lancar. Siswa dengan self efficacy tinggi menullskan ide, situasi atau relasi matematis untuk menyelesaikan soal yang diberikan dengan akurat, lengkap dan lancar. Siswa dengan self efficacy tinggi menuliskan langkah-langkah penyelesaian soal menuju solusi akhir secara matematis dengan akurat, tidak lengkap dan lancar. Hal tersebut dikarenakan siswa dengan self efficacy tinggi tidak menuliskan metode yang digunakan dalam menentukan nilai dari masingmasing variabel. Siswa dengan self efficacy tinggi menuliskan alasan terkait dengan solusi matematika dalam konteks semula dengan akurat, lengkap, dan lancar.

2. Profil Komunikasi Matematis Siswa dengan Self Efficacy Rendah dalam Menyelesaikan Soal Matematika

Siswa dengan self efficacy rendah menuliskan hal-hal yang diketahui dan ditanyakan pada soal dengan akurat, tidak lengkap dan lancar. Ada hal yang diketahui pada soal, dan tidak ditulis dalam lembar jawabannya. Hal tersebut adalah harga hoodie lebih mahal daripada harga kemeja. Siswa dengan self efficacy rendah menuliskan pernyataan dalam soal ke dalam model matematika dengan akurat, lengkap dan lancar. Siswa dengan self efficacy rendah menuliskan ide, situasi atau relasi matematis untuk menyelesaikan soal yang diberikan dengan akurat, lengkap dan lancar. Siswa dengan self efficacy rendah menuliskan langkah- langkah penyelesaian soal menuju solusi akhir secara matematis dengan akurat, tidak lengkap dan tidak lancar. Hal tersebut dikarenakan siswa dengan self efficacy rendah tidak menuliskan metode yang digunakan dalam menentukan nilai dari masingmasing variabel. Terdapat coretan atau koreksian pada lembar jawaban siswa dengan self efficacy rendah. Siswa dengan self efficacy rendah melakukan beberapa kali kesalahan dalam melakukan perhitungan pada saat mensubstitusikan nilai variabel $\mathrm{b}$ ke persamaan 1 . Siswa dengan self efficacy rendah menuliskan alasan terkait dengan solusi matematika dalam konteks semula dengan akurat, lengkap, dan lancar.

\section{Saran}

Berdasarkan hasil penelitian yang telah dilakukan, peneliti mengemukakan beberapa saran sebagai berikut.

1. Dalam penelitian ini, yang menjadi subjek adalah satu siswa dengan self efficacy tinggi dan satu siswa dengan self efficacy rendah serta mempunyai kemampuan matematika tinggi setara. Untuk peneliti lain yang akan melakukan penelitian sejenis, hendaknya memilih subjek tidak hanya dengan kemampuan matematika tinggi setara saja, namun juga subjek dengan kemampuan sedang dan rendah setara.

2. Tinjauan dalam penelitian ini hanya terbatas pada self efficacy siswa. Sebaiknya peneliti lain mengembangkan penelitian ini menggunakan tinjauan lain serta menggunakan subjek dengan tingkat satuan pendidikan yang berbeda.

\section{DAFTAR PUSTAKA}

Alifia, N. N., dkk. 2018. "Kajian Kemampuan Self Efficacy Matematis Siswa Dalam Pemecahan Masalah Matematika". Jurnal Elektronik Pembelajaran Matematika.

Anggraini, N. N. 2017. Profil Berpikir Kritis Siswa Smp Dalam Memecahkan Masalah Aljabar Ditinjau Dari Self Efficacy. Tesis tidak diterbitkan. Surabaya: PPs Universitas Negeri Surabaya.

Ayotola, A., \& Adedeji, T. 2009."The Relationship Between Mathematics Self Efficacy and Achievement in Mathematics". Procedia-Social and Behavioral Sciences.

Bansu, I. A. 2018. Komunikasi Matematik, Strategi Berpikir dan Manajemen Belajar: Konsep dan Aplikasi. Banda Aceh: PeNa. 
Djalali, M. A., dkk. 2012 "Pola Asuh Orangtua Demokratis, Efikasi Diri dan Kreativitas Remaja”. Persona: Jurnal Psikologi Indonesia.

Desmawati. 2015. "Hubungan antara self efficacy dengan kemampuan komunikasi matematik pada siswa SMPN 2 Padang Panjang". Psyche Journal.

Dewi, Izwita. 2009. Profil komunikasi matematis mahasiswa calon guru ditinjau dari perbedaan jenis kelamin. Disertasi tidak diterbitkan. Surabaya: PPs Universitas Negeri Surabaya.

Heris Hendriana, G. K. 2019. "Self efficacy dan Kemampuan Komunikasi Matematis Siswa SMP". Jurnal Nasional Pendidikan Matematika.

Hudojo. 2005. Kapita Selekta Pembelajaran Matematika. Malang: Universitas Negeri Malang.

Istiani, A., dkk. 2019. “Analisis Kemampuan Komunikasi Matematis Siswa Dalam Menyelesaikan Soal Cerita Matematika". Jurnal Edumath.

Mahmudi, Ali. 2009. "Komunikasi dalam Pembelajaran Matematika". Makalah Termuat pada Jurnal MIPMIPA UNHALU.

Miles \& Huberman, A. 2014. Analisis Data Kualitatif. Terjemahan Tjetjep Rohendi Rohidi. Jakarta: UI Press.

Nasution, M. 2013. "Pembelajaran Komunikasi Matematika dalam Think Pair Share". Jurnal Logaritma.

National Council of Teacher Mathematics. 2000. Principles and Standarts for School Mathematics. Reston: Virginia.

Nugraha, T. H., dkk. 2019. "Analisis Kemampuan Komunikasi Matematis Siswa Berdasarkan Perbedaan Gender". Edumatica

Organization of Economic and Cooperation Development. 2013. Draft Mathematics Framework. PISA.
Ormrod, J.E. 2008. Educational Psychology Developing Learners. Terjemahan Amitya Kumara. Jakarta: Erlangga.

Qohar, Abdul. 2011. "Mathematical Communication: What and How To Develop It In Mathematics Learning?". Makalah disajikan dalam International Seminar and the Fourth National Conference on Mathematics Education 2011 "Building the Nation Character through Humanistic Mathematics Education". Yogyakarta: Department of Mathematics Education, Yogyakarta State University.

Rahmawati, Z. 2015. "The Study of Academic Burnout in Students with High and Low Level of Self Efficacy". Procedia-Social and Behavior Sciences.

Rausch, A. 2017. "Complexity, Accuracy, Fluency as a Communication Paradigm: From Theory to Instructional Curriculum". Japanese Journal of Communication Studies.

Rustika, I Made. 2012. Efikasi diri: Tinjauan Teori Albert Bandura. Buletin Psikologi Fakultas Psikologi Universitas Gajah Mada.

Sadewi, A. I., dkk. 2012. "Meningkatkan Self Efficacy Pelajaran Matematika Melalui Layanan Penguasaan Konten Teknik Modeling Simbolik". Indonesian Journal of Guidance and Conseling Theory and Aplication.

Suharnan. 2005. Psikologi Kognitif. Surabaya: Srikandi.

Ulya, Rif'ah., dkk. 2016. "Kemampuan Pemecahan Masalah Ditinjau dari Self Efficacy Siswa Dalam Model Pembelajaran Missouri Mathematics Project". Unnes Journal of Mathematics Education Research.

Zimermann, B.J. 2015. "Self Efficacy: An Essential Motive to Learn". Contemporary Educational Psychology.

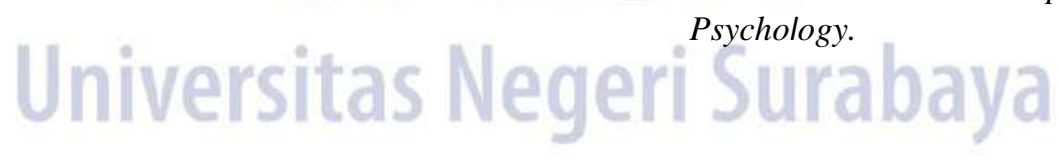

